\title{
日本と中国のトキの音声について
}

\author{
小笠原胃
}

\section{Acoustic Sounds of Japanese Crested Ibis Nipponia nippon in Japan and China}

Ko Ogasawara*

\begin{abstract}
I analyzed the several acoustic sounds of Japanese Crested Ibis Nipponia nippon which is one of the species in danger of extermination in the world, by means of sound spectrograph (Rion SG-07). The acoutic sounds of so-called Kinchan (female) in the cage (Toki Hogo Center, Sado, Niigata Pref. Japan) and of the breeding one in China were compared with several sonagrams shown by the pattern of 7.2 second $(2.5 \mathrm{KHz})$. Dement'ev (1969) reported that voice of Japanese Crested Ibis resembles croaking of Raven, but it was, in fact, much louder, and it may be expressed as "ka-ga, ka-ga, ka-ga" and sometimes as "kag, kag, kag". In this study, I recorded three kinds of different sonagrams of Kinchan (Kwá, kwá-u and Kwá-n) and four kinds of sonagrams in China (Kwá, kwa-u, Kwan and Kwá-n). The sonagrams of Kwa-n in Kinchan and those in China are said to be similar sounds, but it is clear that both sonagrams are somewhat different from each other.
\end{abstract}

日本で野外からトキ (Nipponia nippon Temm.) が姿を消したのは 1981 年 1 月である。こ のトキに関する報告は数多いものの, 音声に関するものは, 佐藤 (1968) の「県民の鳥, トキ」, 佐藤 (1978) の「はばたけ贞鷟」や村本 (1972) の「能登のトキ」などに, その生態観察の折 に聞かれたトキの鳴き声が記載されているにすぎない。しかしその表現は似ているものの，一 致しているものが少ない。

Dement'ev et al. (1969) はトキが ka-ga, ka-ga, kaga や時には kag, kag, kag のように 鳴くと報じている。

北条（1973）は「呼称と伝承に探る一あきたの野鳥一」のなかで，秋田県ではトキは大正初 期までは各地に生息していたと思われると報じ, 特に営巣の上からも, 採䬣の上からも好条件 の整った八郎潟周辺から男鹿の村落森林田畑地帯は有数の生息地であったようであり, 従って トキに関する伝承のゆたかさは，わが秋田が全国随一であるのもよくこれを物語っていると報 じている。

北条 (1973) は, さらに中央の文献から，トキの呼称についてまとめ，トキはッキとトオの 混合形として成立したものであろうとし，平安時代の「和名類聚称」には「自ら名を呼ぶ鳥な り」と説明しているという。

また安田（1983）はトキに関する古文献の総まとめをおこない，呼称についてもふれている。

Received 15 February 1985

* Laboratory of Biology, Faculty of Education, Akita University, Tegata-Gakuen-cho, Akita 010. 
Table 1. Nameing of Japanese Crested Ibis in the old times (Hojo 1973)

\begin{tabular}{|c|c|c|}
\hline 奈良朝時代 & ツキ (tuki) & タタ タ，タフ，タウ \\
\hline 平安一鎌倉時代 & ツキ (tuki) & $\begin{array}{l}\text { タタ } \Rightarrow(\operatorname{tatawo}) \\
\text { タ }(\mathrm{tawo}) \\
\text { タウ }(\mathrm{tau})\end{array}$ \\
\hline 窒町時代 & トオ (tô) & (ô) はロを広げたオの長音 \\
\hline 江戸時代 & トキ & 室町末期にすでに現われたと思われる \\
\hline
\end{tabular}

北条 (1973) はトキの呼称について，その鳴き声と関連させ，Table 1 のようにまとめてい る。北条 (1973) は秋田のトキの呼称として，ダオ，ダオンコ，ダウ，ダオサギ，ダオシギを あげ，こうした呼称の成立を説明する伝承は，次のようであるとしている。

1) ダオン，ダオンと鼻にかけて鳴く。

2) 鼻グサレの鳴声で, ダオンと鳴く。

3）自分の名前を呼ぶのはダオだけだ。

つまり，北条 (1973) は，ダオといら鳥の名は，その鳴声の「ダオン」をそのまま名前とし たもので，このことから，中央古語のタタ れ，秋田人がダオン，ダオンといさをしく聞いたのを，都人はやさしく，タョン，タヨンある いはターウ，ターウと聞いた次第であるという興味あるトキの呼称について報じている。

さて，佐藤（1978）と村本（1972）がそれぞれ記載しているトキの音声表現と，それに関連 した生態の記載について比較した (Table 2)。

Table 2 には音声表現がほぼ似ているものを並べたが，両氏の音声表現が一致しているもの はない。音声を言葉で表現することの困難さを示している一例といえよう。

前述した北条 (1973) の呼称であるダオン・タヨン或いはターウの表現は, 佐藤 (1978) や 村本（1972）には現われていず，ターウがややクワーウに似ているように思觉る。

そこで著者は鳥類の音声の声紋分析に興味を持っていることから，現在新潟県佐渡トキ保護 センターで飼育中の金ちゃん（雌）の鳴き声を同センターの近辻宏帰氏に録音していただき，

Table 2. Expressions of the acoustical sounds of Japanese Crested Ibis by Sato (1987) and Muramoto (1972).

\begin{tabular}{|c|c|c|}
\hline 佐藤 1987 & 村本 1972 & 生態の記録 \\
\hline $\begin{array}{l}\text { クワーウ } \\
\text { クワーウ }\end{array}$ & クウーウ & 大空を飛ぶ時 \\
\hline $\begin{array}{l}\text { クワー, クワー } \\
\text { クワー, クワー }\end{array}$ & (クワウン, クワウン) & 警戒音 \\
\hline クワウ，クワウ & クワッ, クワッ & ねぐらで或いはねぐらから飛び立つ時 \\
\hline & $\begin{array}{l}\text { クアン } \\
\text { グゥッ, グッッ } \\
\text { カック, カック }\end{array}$ & $\begin{array}{l}\text { 仲間への伝達 } \\
\text { 餌場へおりる時 } \\
\text { 求愛行動 }\end{array}$ \\
\hline
\end{tabular}


さらに近年中国科学院動物研究所, 劉蔭増博士が 1981 年及び 1982 年に録音したテープを環 境庁自然保護局鳥獣保護課長並びに江原秀典調査官（現在日本鳥類保護連盟）よりお送りいた だいた。

現在日本では野生のトキがいないだけに，佐藤（1978），村本（1972）の記載したものを参 考にしながら，それぞれの音声の声紋を記載しておくことは，それだけでも十分貴重であると 考えられ，さらに幸い中国の野生下でのトキの鳴き声の声紋とを比較することができた。本来 であれば著者自身がトキの鳴き声を聞き, その時のトキの状態, つまり行動様式を記録し, 音 声の意味づけをすべきであるが，佐渡のトキは，今は全てケージの中にあり，中国のトキの音 声も録音テープのみである。

声紋分析にあたり, 種々御教示いただき,お手伝いいただいた秋田大学教育学部教育工学セ ンターの藤垣雅明氏に感謝申し上げる。

金ちゃんの音声を録音して下さったトキ保護センターの近辻宏帰氏，多くの情報を御教示い ただいた佐藤春雄氏，中国の野生トキの録音テープ入手にお骨おりいただいた環境庁自然保護 局鳥獣保護課長並びに江原秀典調査官（現在日本鳥類保護連盟）及び心良く録音テープを提供 して下さった中国科学院動物研究所, 劉蔭増博士に対し, 心から感謝申し上げる。

\section{I. 金ちゃんの音声の声紋分析結果}

現在, ケージの中で飼育中の金ちゃんは，1968 年 3 月 15 日に保護されたもので, 約 18 年間飼育されている。その後, 1981 年 1 月野外のトキ 5 羽が次々と捕獲され, 人工飼育によ るトキ増殖計画が実施されている。

著者はその前年の 1980 年 2 月, 初めて野生のトキを観察することができた。その折, 佐 藤春雄氏から，佐渡のトキに関する多数の資料をいただき，実に多くのトキの生態についてう かがってきた。著者は幸運にも，丁度ねぐらに帰るトキ 4 羽の姿を見ることができた。その後 ケージの中の金ちゃんを外から見せていただいた。従ってトキの鳴き声や生態についての知見 は, 前述の著書やトキ保護センターの近辻宏帰氏や佐藤春雄氏より得たものである。

近辻氏により録音された金ちゃんの鳴き声をできるだけ雑音の少ないもの，よく似た音声に 分類し, リオン声紋分析器 (Rion SG-07) により, 7.2 称, $2.5 \mathrm{KHz}$ のパターンで分析した。

Fig. 1 にはクワ (Kwá) 或いはクワッ(Kwǎ) 系統の音声のソナグラムを示した。Fig. 1A には，短かくクワ，クワ Kwá Kwa）と連続的に鳴いているもので, 明らかに7つのフォルマ ントが認められる。

Fig. 1 の $\mathrm{B}$ と C も， A とよく似ているが， B と C はやはり短かいクワックワッ (Kwã Kwă) と聞こえる音声で， 7 8 つのフォルマントが認められる。B にはクワッ (Kwǎ) 音の 直前に，前そうが入るのも認められ，ククワッククワッ(Kukwǎ Kukwǎ) と聞える (B の 6 音以降)。C 8 は 9 つのフォルマントがあり, 基本的にはクワックワッといら連続した 鳴き声である。Cのソナグラムをよく比較してみると 3 番目以降のソナグラムは前二者にくら

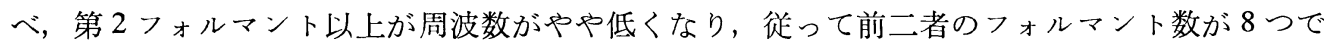
あるのに対し， 3 番目以降のソナグラムでは 9 つのフォルマントが認められ, 実際これらの音 声は前二者より, やや低いクワッ (Kwǎ) 音に聞こえる。 


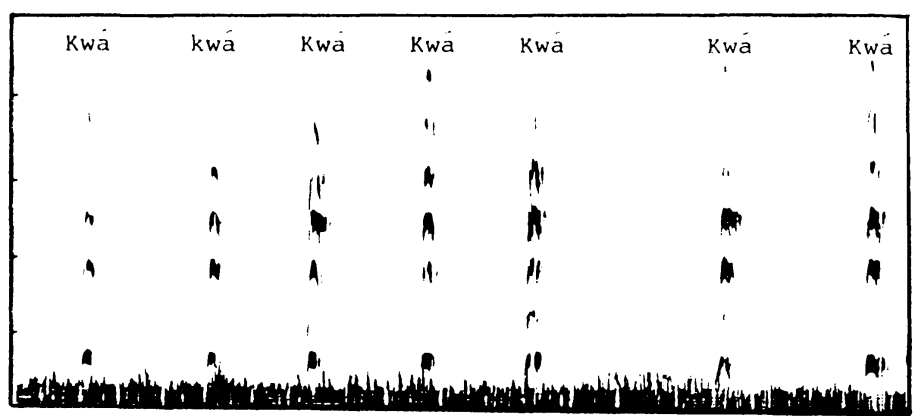

A

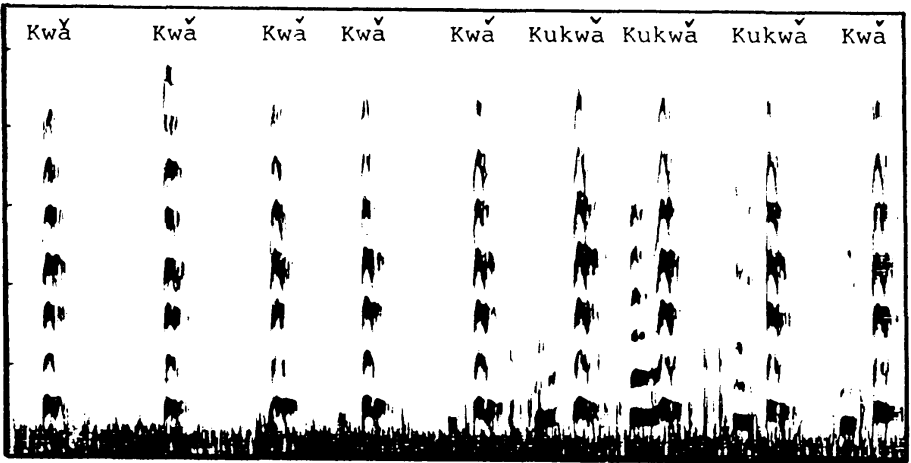

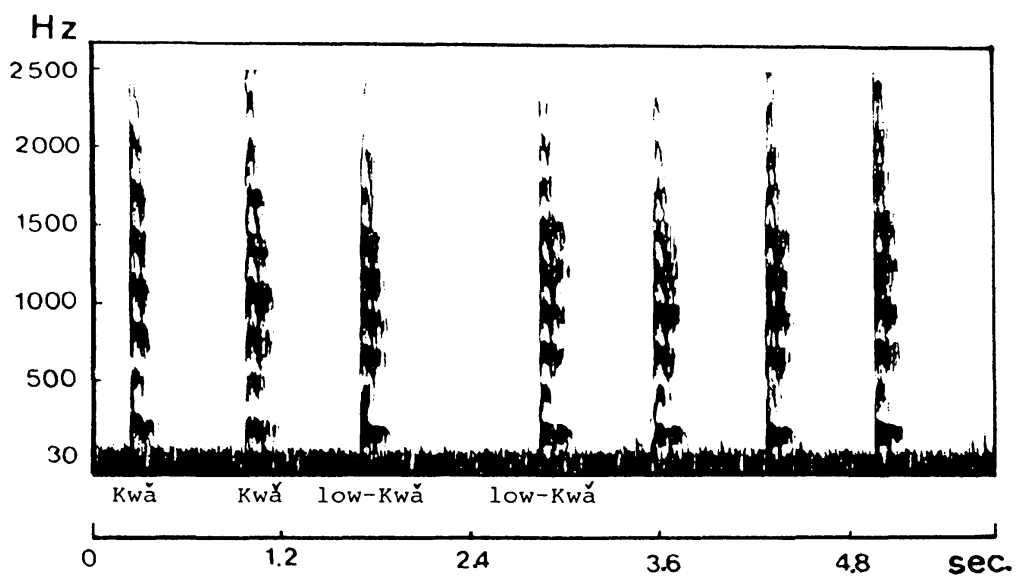

Fig. 1. Sonagrams of so-called Kinchan in the cage (Toki Hogo Center, Sado, Niigata Pref.), 1981.

しかし，A， B，C とも基本的には同じ音声と思われ，村本（1972）のクワッ音 (Table 2) に 相当する音声と思われる。

Fig. 2 にはクワーウ (Kwa-u) (A) とクアーン (Kwá-n) (B) 音を示した。A にはクワ ク ワククワーウ クワ ククワ クックワ クワ (Kwá Kwá Kukwá-u Kwá Kukwá Kukwa Kwá) と聞こえる音声のソナグラムを示した。その中で， 3 番目のククワーウ (Kukwá-u) 音 


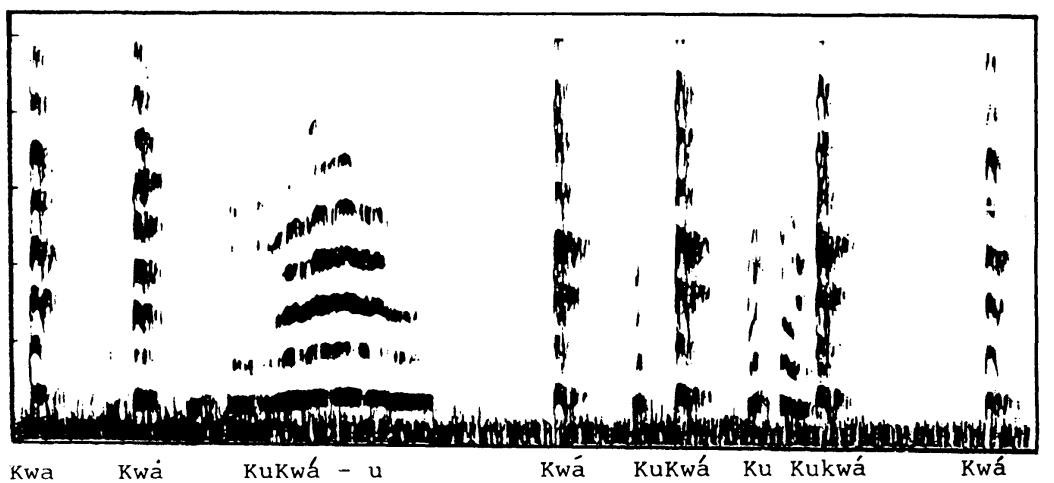

A

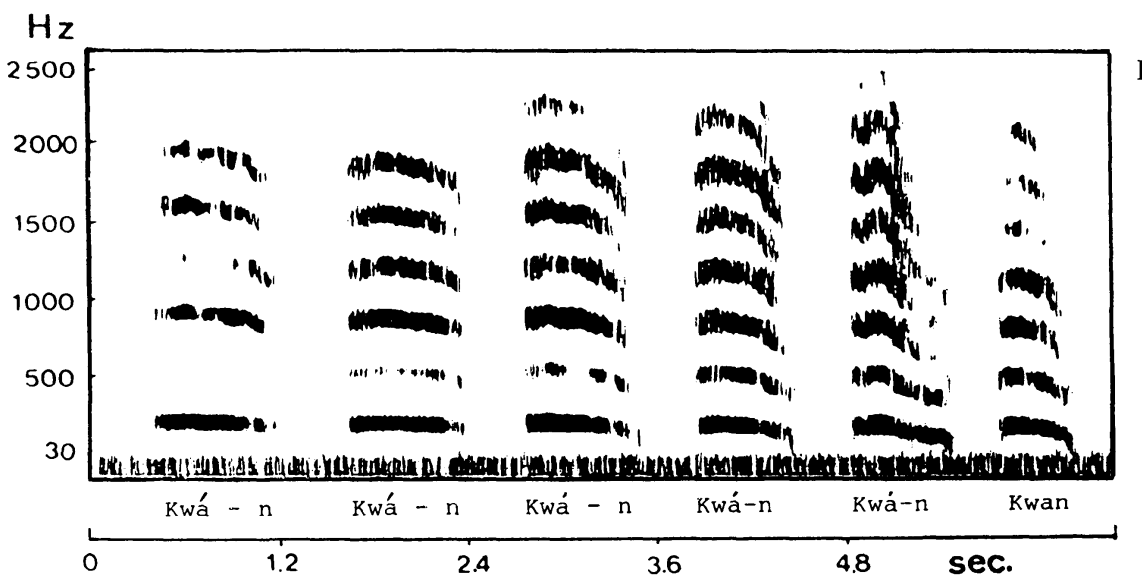

Fig. 2. Sonagrams of so-called Kinchan in the cage (Toki Hogo Center, Sado, Niigata Pref.), 1981.

が特異な音声で，これはク $(\mathrm{Ku})$ と前そうが入り，次いでかなり長い（約 1.2 称）クワーウ (Kwá-u) 音が続く音声であり, 佐藤 (1978) のクワーウ クワーウ音に相当する音声と思われ る。として本音声が北条（1973）のいらダオン或いはターウと聞かれた音声のように見うけら れる。本音声は佐藤（1978）によると大空を飛ぶ時に鳴くという。

Fig. 2 の B には A のクワーウに似た音声であるが，クワーウより短かく（約 0.8 称）, クアーン クアーン (Kwá-n Kwá-n) と聞こえるソナグラムを示した。これは村本 (1972) の クアン クアン (Kwán Kwán) 音に相当するものと思われ, 仲間への伝達の折に聞かれると いら。

本音声のソナグラムの特徵は，7 8 つのフォルマントが認められ，比較的長い音声である ことである。

以上金ちゃんの音声で, 基本的には 3 つの明らかに異ったソナグラムが認められたが，野外 で自由に生活しているトキの場合には，もっと多くの音声があるものと思われる。特に繁殖期 には, 特有の音声があるものと思われ, 村本 (1972) が記載している求愛行動の折に発するカ 
ック カック音等は, 金らゃんの録音テープからは得られなかった。

\section{II. 中国の野生トキの音声の声絞分析結果}

中国科学院動物研究所, 劉蔭増博士が中国陝西省泰嶺山脈山中で 1981 年および 1982 年の 繁殖期にトキの鳴き声を録音したものを提供して下さった（劉 1984）。そのテープから比較的 単音で, 雑音の少ない音声を編集し, 声紋分析を行った。1981 年のものは雑音が多く, 従っ て主に 1982 年の音声からソナグラムを得, 比較した。

Figs. 3，4 は中国の野生トキの音声のソナグラムで，まず Fig. 3 の C は金ちゃんの音声 (Fig. 1A) と同様で, クワ クワ (Kwá Kwá) 音で, 各フォルマントの周波数帯もほぼ同様で ある。

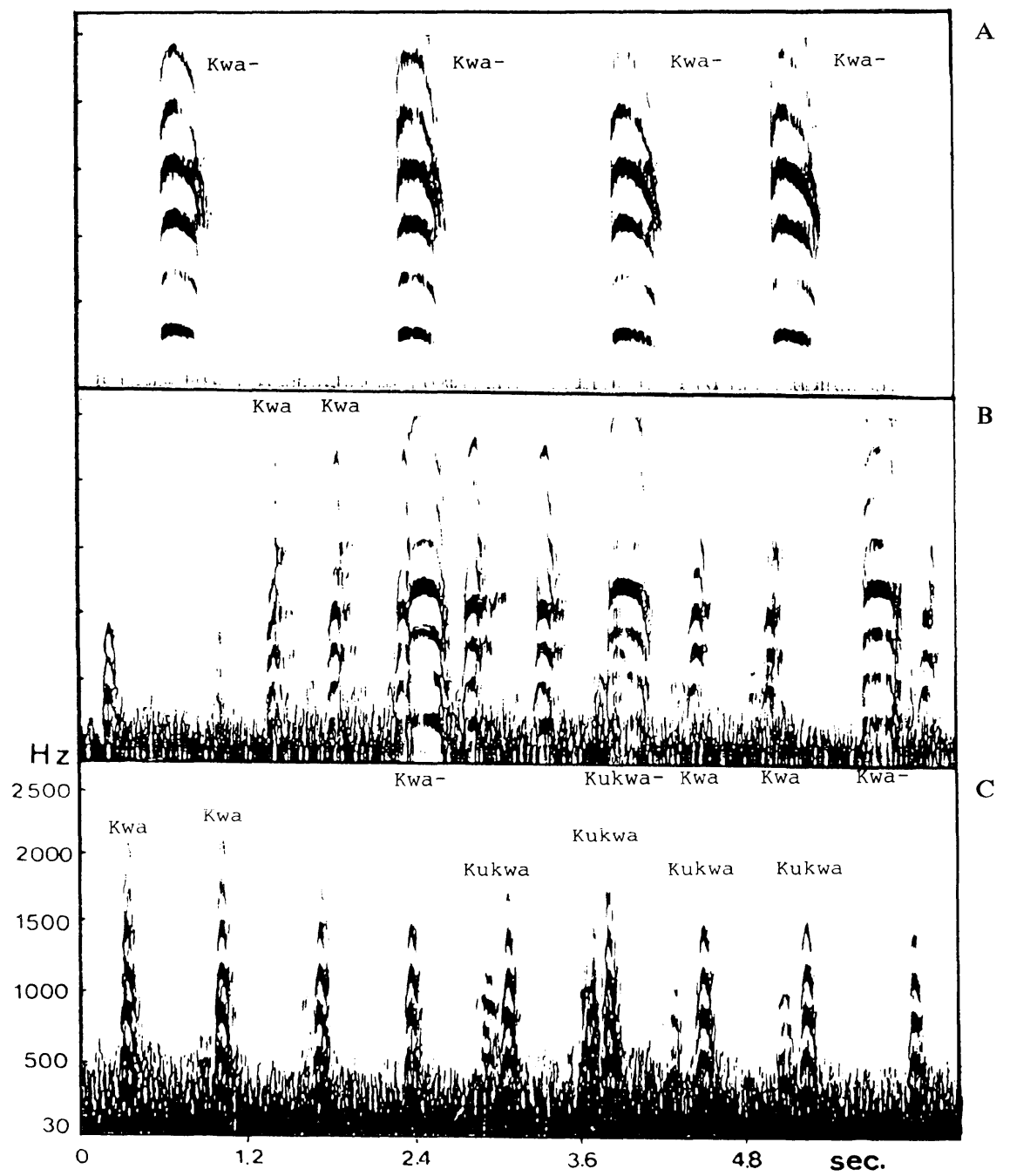

Fig. 3. Sonagrams of Japanese Crested Ibis in nature of China, 1982. 

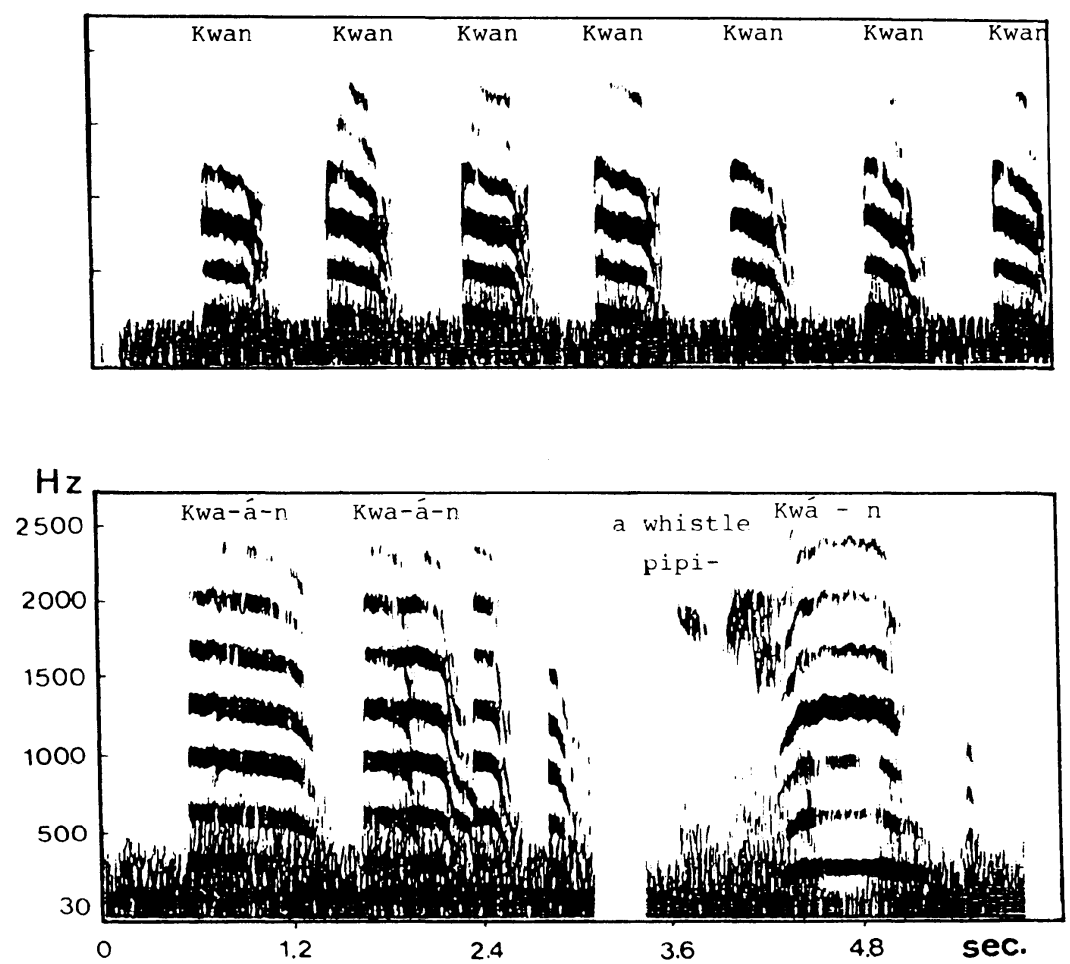

Fig. 4. Sonagrams of Japanese Crested Ibis in nature of China, 1982.

本音声はほぼ 0.8 称間隔で鳴いたものであり，繁殖期に巣の近くで鳥いていたものであろう。

Fig. 3 の A に示したソナグラムは金ちゃんには認められず, テープを聞いたところでは, クワー クワー (Kwa- Kwa) と比較的長く（0.4 称）鳴く音声である。本音声は佐藤 (1978) のクワー クワー (Kwa- Kwa) (Table 2) 音に相当するもののようである。

Fig. 3 の B にはクワ クワ (Kwá Kwá) 音と A のクワー (Kwá-) 音の混った一連の鳴 き声のソナグラムを示した。このクワー (Kwa-) 音は金ちゃんにも認められ，クワ (Kwá) 音 を少し長く伸ばした音声のように思われる。

Fig. 4 の A にはクアン クアン (Kwan Kwan) 音のソナグラムを示した。本音声も金ち やんには認められず，6つのフォルマントまで認められ，クアン クアン (Kwan Kwan) と 比較的長く鳴く (0.6 称) 音声であり, 村本 (1972) のクアンに相当するものと思われる。村 本（1972）によれば仲間への伝達のための音声であるという。本音声も繁殖期巣の近くで鳴い ていたものであろう。

Fig. 4 の B にはクアーアーン クアーアーン クアーン (Kwa-á-n Kwa-án Kwá-n) と 聞こえる一連の音声のソナグラムを示した。そのクアーアーン音は, クアーンとクアーンとい ら2 音が連続して発せられた音声のように思われる。B の右側は人の口笛で, ピッピィー音に 反応して，比較的長くクアーンと鳴いた音声である。両者とも金ちゃんのクアーン (Kwá-n) 音 (Fig. 2 の A と B) に似てはいるものの, そのソナグラムはそれぞれ異っている。この違 
いは個体による相違か，地域差か或いは異った音声であるかは，もっと多くの音声を分析して みなければ明らかにできない。

以上日本のトキ, 飼育中の金ちゃんの鳴き声と中国で繁殖中に録音されたトキの鳴き声をり ナグラムで比較検討した。その結果, 金ちゃんでは明らかに異なる 3 種のソナグラムが記録さ れ，一方中国のトキでは 4 種のソナグラムが記録された。

金ちゃんと中国のトキでは明らかに同じ音声が一種認めら (クワ クワ Kwá Kwá), クア ーン音はほぼ似てはいるものの, ソナグラムの比較では異っている。従って中国のトキの音声 のらち，3 種類は金ちゃんのものと異っているといえよう。

しかし金ちゃんの場合も中国のトキの場合も，もっと多くの音声のソナグラムを比較してみ る必要があることはいうまでもないが, 現在入手できた音声テープからでは, これ以上の比較 は無理である。しかし残念ながら，日本では野外では生息していないトキであり，その音声の ソナグラムの一部でも記録しておくだけで価值あるものと考劣る。

\section{引用文 献}

Dement'ev et al. 1969. Birds of the Soviet Union, vol. II.

北条忠雄 1973. 呼称と伝承を探る一秋田の野鳥一, あきたの野鳥, 秋田県環境保健部自然保護課.

村本義雄 1972. 能登のトキ…七七年間の観察記録 $\cdots$. 北国出版社, 金沢市.

劉 蔭增 1984. 中国のトキ, ニュートン 4, No. 12 .

佐藤春雄 1968. 県民の鳥, トキ, 新潟県農林部治山課.

佐藤春雄 1978。はばたけ朱鴑, 研成社, 東京.

安田 健 1983. トキの文献 (その 1), 応用鳥学集報 3: 28-40.

安田 健 1984. トキの文献 (その 2). 応用鳥学集報 4: 8-28. 